\title{
КЛАСТЕРИЗАЦІЯ ФУНКЦІОНАЛЬНИХ СТАНІВ ОРГАНІЗМУ. ПІЛОТНЕ ДОСЛІДЖЕННЯ
}

\author{
О. П. Мінцер, В. П. Карленко, \\ Я. О. Шевченко, О. О. Суханова \\ Національний університет охорони здоров'я України імені П. Л. Шупика \\ ${ }^{1}$ Національний університет фрізичного виховання і спорту України
}

\begin{abstract}
Розглянуто питання та проведено пілотний аналіз даних про можливості виділення стабільних станів фрункціонування організму при фрізичних навантаженнях. В якості прикладу обрано показники ергоспірометрії та динаміки частоти серцевих скорочень у 7 чоловіків і 6 жінок, основного складу збірної команди України 3 біатлону. Визначено можливість виділення кластерів сталих фрізіологічних станів спортсменів-біатлоністів, їх повторюваність, взаємозв'язок із фрізіологічними показниками та виявлено бар'єри, що негативно впливають на своєчасне корегування фрункціонального стану спортсменів. З'ясовано, що проведена кластеризація фрункціонального стану в спортсменів у процесі змагальної діяльності підтвердила гіпотезу про наявність у них декількох сталих станів, виявлення та інтерпретація змін яких для досягнення максимального результату на змаганнях можлива при забезпеченні певної тривалості моніторингу та персоналізованого оцінювання траєкторії змін. Більшість методів автоматичної кластеризації станів у спортсменів дають близькі результати. Враховуючи, що біологічні об'єкти здатні створювати свої власні норми та постійно гармонізувати свої можливості для забезпечення стабільності фрункціонування, вкрай потрібна фрормалізація біологічних концепцій про сталі стани. Застосування парадигми сталих станів як комбінації незмінних фрізіологічних показників (при не екстремальних впливах зовнішніх фракторів) дозволяє суттєво полегшити вирішення завдання прогнозування результатів тренувального процесу в спортсменів.
\end{abstract}

Ключові слова: кластеризація, фрункціональні стани, діагностичний процес, стабільні стани, альтернативні сталі стани.

\section{CLUSTERIZATION OF FUNCTIONAL STATES OF THE ORGANISM. PILOT STUDY}

\author{
O. P. Mintser, V. P. Karlenko ${ }^{1}$, \\ Ya. O. Shevchenko, O. O. Sukhanova \\ Shupyk National Healthcare University of Ukraine \\ ${ }^{1}$ National University of Ukraine on Physical Education and Sport
}

Background. Issues are considered and a pilot analysis of data on the possibility of allocating stable states of the body during exercise. As an example, selected indicators of ergospirometry and dynamics of heart rate (HR) in 7 men and 6 women, the main members of the national team of Ukraine in biathlon. The purpose of the study is to determine the possibility of allocating clusters of stable physiological states of biathletes, their recurrence, the relationship with physiological indicators and to identify barriers that negatively affect the timely adjustment of the functional state of athletes. Materials and methods. Results. It is concluded that the clustering of the functional state of athletes in the competitive process confirmed the hypothesis that they have several stable states, detection and interpretation of changes which are possible to achieve maximum results in competitions with a certain duration of monitoring and personalized assessment of change trajectory. Most methods of automatic clustering of states in athletes give similar results. Considering that biological objects projects are able to create their own norms and constantly harmonize their capabilities to ensure the stability of functioning, it is essential to formalize biological concepts of stable states.

Conclusions. The use of the paradigm of steady states as a combination of constant physiological indicators (under non-extreme influences of external factors) can significantly facilitate the solution of the problem of predicting the results of the training process in athletes.

Key words: clustering, functional states, diagnostic process, stable states, alternative steady states. 


\title{
КЛАСТЕРИЗАЦИЯ ФУНКЦИОНАЛЬНОГО СОСТОЯНИЯ ОРГАНИЗМА. ПИЛОТНОЕ ИССЛЕДОВАНИЕ
}

\author{
О. П. Минцер, В. П. Карленко \\ Я. А. Шевченко, О. А. Суханова \\ Национальный университет здравоохранения Украины имени П. Л. Шупика \\ ${ }^{1}$ Национальный университет фризического воспитания и спорта Украины
}

\begin{abstract}
Рассмотрены вопросы и проведен пилотный анализ данных о возможности выделения стабильных состояний фрункционирования организма при фризических нагрузках. В качестве примера выбраны показатели ергоспирометрии и динамика частоты сердечных сокращений у 7 мужчин и 6 женщин, основного состава сборной команды Украины по биатлону. Определена возможность выделения кластеров постоянных физиологических состояний спортсменовбиатлонистов, их повторяемость, взаимосвязь с фризиологическими показателями и выявлены барьеры, негативно влияющие на своевременную корректировку функционального состояния спортсменов. Сделан вывод о том, что проведенная кластеризация функционального состояния у спортсменов в процессе соревновательной деятельности подтвердила гипотезу о наличии у них нескольких постоянных состояний, выявление и интерпретация изменений которых для достижения максимального результата на соревнованиях, возможна при обеспечении определенной продолжительности мониторинга и персонализированной оценки траектории изменений. Большинство методов автоматической кластеризации состояния у спортсменов дают близкие результаты. Принимая во внимание, что биологические объекты способны создавать свои собственные нормы и постоянно гармонизировать свои возможности для обеспечения стабильности фрункционирования, крайне необходима фрормализация биологических концепций относительно устойчивых состояний. Применение парадигмы устойчивых состояний как комбинации постоянных фризиологических показателей (при не экстремальных воздействиях внешних фракторов) позволяет существенно облегчить решение задачи прогнозирования результатов тренировочного процесса у спортсменов.
\end{abstract}

Ключевые слова: кластеризация, фрункциональные состояния, диагностический процесс, стабильные состояния, альтернативные стабильные состояния.

Вступ. Поняття стабільних станів використовується вже довгий час. Ймовірно, вперше воно було застосовано при аналізі складних систем в біології, екології, соціології тощо. Наприклад, в екології теорія альтернативних стабільних станів (часто званих альтернативними стабільними станами) доказує, що екосистеми можуть існувати в декількох «станах» (наборах унікальних біотичних і абіотичних умов). Ці альтернативні стани вважаються стабільними в екологічно значущих тимчасових масштабах. Екосистеми можуть переходити з одного стабільного стану в інший, що відомо як зрушення стану при діях різних факторів. В наслідку дії екологічних зворотних зв'язків екосистеми виявляють стійкість до зрушень станів і тому схильні залишатися в одному стані, якщо обурення незначне. Альтернативна теорія стабільних станів передбачає, що дискретні стани розділені екологічними порогами, на відміну від екосистем, які плавно та безперервно змінюються уздовж градієнта навколишнього середовища.

Одними $з$ перших, хто подав потенційні приклади багатьох стабільних станів були морські екосистеми [6, 7]. Деякі з них детально досліджені, але відмінності між альтернативними станами виявилися занадто тонкими. Більш того, оскільки один стан природно набагато частіше трапляється, більшість середовищ, природно, підтримують лише один тип. Можливість альтернативних стабільних станів нещодавно отримала чергову увагу в контексті морської біології збереження. Підкреслимо, що екосистеми з альтернативними стабільними станами характеризуються механізмами позитивного зворотного зв'язку, які стабілізують переходи. Це може частково пояснити, чому відбувається повернення до початкових умов після антропогенних порушень повільніше, ніж очікувалося. Зауважимо, також, що вивчення спільнот забруднених організмів було першим суттєвим застосуванням ідеї множинних стабільних станів в екології морських спільнот.

У фізіологічних дослідженнях людини найбільш досліджено сталі стани в спорті. Обумовлено це тим, що отримання правильного оцінювання функціонального стану спортсмену є ключовим аспектом тренувальної роботи. Воно дає пояснення різних проблем тренувального процесу, дозволяє забезпечити його корекцію, інформує про можливі результати під час спортивного навчання. Діагностичний процес - це складна спільна діяльність, що включає в себе фізіологічні міркування, процедури збирання, оцінювання валідності та оброблення інформації для визначення стану спортсмена. Діагностичні помилки в оцінюванні 
стану спортсмена можуть завдати їм шкоди не тільки в плані досягнення найкращого фізичного стану, але навіть і в сенсі перешкод або затримки відповідної корекції стану, надаючи непотрібне або шкідливе лікування чи приводячи до психологічних або фінансових наслідків. Відповідно вдосконалення діагностичного процесу не тільки можливо, але і являє собою моральний, професійний і громадський імператив тренерського складу.

Вдосконалення системи управління тренувальним процесом на основі об’єктивізації знань про структуру змагальної діяльності та підготовленості з урахуванням як загальних закономірностей становлення спортивної майстерності в конкретному виді спорту, так й індивідуальних можливостей спортсменів $є$ одним із напрямів удосконалення системи олімпійської підготовки спортсменів в олімпійському спорті. Цей напрям, що спирається на можливості сучасної діагностичної техніки та інформаційних технологій, у даний час є одним із основних резервів удосконалення системи спортивного тренування, оскільки дозволяє створити необхідні умови для раціонального управління станом спортсмена та протіканням адаптаційних змін, що забезпечують відповідність рівня підготовленості планованої структури змагальної діяльності заданому спортивному результату $[1,11]$.

Мета роботи: визначити можливість виділення кластерів сталих фізіологічних станів спортсменів-біатлоністів, їх повторюваність, взаємозв’язок із фізіологічними показниками та виявити бар’єри, що негативно впливають на своєчасне корегування функціонального стану спортсменів.

Матеріал і методи дослідження. Апостеріорно проаналізовано деякі дані тренування та динаміки частоти серцевих скорочень (ЧСС) у 7 чоловіків і 6 жінок, основного складу збірної команди України з біатлону, що здійснювали підготовку на заключному етапі (2013 рік) до участі в зимових Олімпійських іграх 2014 року в Сочі. Серед них були олімпійські чемпіони в естафетній гонці, бронзова призерка в спринтерській гонці, чемпіони та призери чемпіонатів світу.

Для аналізу індивідуальних особливостей динамічної ідентифікації спортсменів-біатлоністів та їхніх середньо-групових даних виконано понад 700 людино-досліджень.
Проведений кластерний аналіз даних протоколу тестування на тредмілі в лабораторії спортивної медицини в м. Вуокатті, Фінляндія (ергоспірометрія), зокрема, щохвилинна динаміка дистанційної реєстрації: ЧСС (показник С1), споживання кисню та інші показники.

Оброблення матеріалу проводилось за допомогою пакету програм StatSoft, STATISTICA 10 (data analysis software system). Обчислювалися показники центральної тенденції та виділялися певні кластери методами одиночного зв'язку, методом Уорда, з використанням зваженого та незваженого центроїдного методу тощо. Візуалізація процесів таксономії здійснювалася методом побудови вертикальних дендрограм. Беручи до уваги невелику кількість показників функціонального стану спортсменів, кластеризація здійснювалась лише в просторі об’єктів.

Результати та їх обговорення. Постановка проблеми. Загально визнаного визначення поняття «Стаціонарний стан» не існує. В біохімії під ним розуміється ситуація, в якій певні параметри клітин або органів, зазвичай, концентрації молекул, постійні в часі. Під сталим станом у фізіології (також відомим як гомеостаз) розуміється система, в якій певні змінні не змінюються, але щоб підтримувати ці змінні повинна постійно додаватися енергія, при чому в динамічних системах спостерігається динамічна рівновага.

В спортивній медицині за характером постачання організму кисню виділяють два види стійкого стану:

- уявний стійкий стан (при роботі великої і субмаксимальної потужності), коли спортсмен досягає рівня максимального споживання кисню, але це споживання не покриває високого кисневого запиту й утворюється значний кисневий борг;

- справжній стійкий стан при роботі помірної потужності, коли споживання кисню відповідає кисневому запиту та кисневий борг майже не утворюється [9].

Механізм виникнення стійкого стану при тривалій роботі має індивідуальні відмінності. В одних людей підвищена доставка кисню забезпечується головним чином збільшенням легеневої вентиляції. У інших при відносно невеликому збільшенні цього показника стійкий стан обумовлено високим коефіцієнтом дифузії кисню в легенях і підвищеною 
його утилізацією. В деяких випадках стійкий стан досягається шляхом підвищення функцій органів кровообігу, що поєднується з відносно помірним посиленням зовнішнього дихання [10].

При уявному стійкому стані внутрішні органи, працюючи на межі, не можуть повністю забезпечити високу кисневу потребу. Про наявність стійкого стану в цих випадках говорять лише тому, що фізіологічні процеси, поступово посилюючись у періоді відпрацьовування, досягають майже межи та утримуються на цьому рівні протягом відносно тривалого часу.

Взагалі, парадигма сталих станів постійно дискутується в літературі. Наприклад, у дослідженнях науковців [2, 3, 4], де розглядаються проблеми максимальних метаболічних стійких станів (ММСС). Як підкреслюють автори, ММСС відноситься до інтенсивності, з якою організм людини переходить від «стаціонарних» до «нестаціонарних» метаболічних реакцій на тривалі фізичні навантаження. Важливим висновком авторів $€$ те, що «коли організм спортсмена знаходиться в стійкому метаболічному стані, вправи з постійною силою або темпом викликають стабільні реакції, тобто концентрацію лактату в м’язах і крові, кислотно-лужний баланс, доступність фосфокреатину та споживання кисню $\left(\mathrm{VO}_{2}\right)$ досягає плато і стабілізується. В метаболічно нестабільному стані інтенсивність вправ досить висока, реакції не стабілізуються; концентрація лактату в м’язах і крові поступово підвищується». Отже, ММСС визначає межу між інтенсивністю вправ, упродовж яких спостерігаються ці стаціонарні та нестаціонарні реакції, те, що деякі називають межею між областями аеробної та анаеробної потужності.

В наших дослідженнях під сталими станами розуміли певні комбінації показників функціонального стану людини, що зберігаються незмінними при не екстремальних впливах навколишнього середовища.

Отримані результати. Розглянуто можливість виділення сталих станів при підготовці спортсменів високого рівня.

Особливістю авторського підходу є гіпотеза про існування декількох стабільних станів у спортсменів, оскільки працездатність професійних спортсменів упродовж тренувальної діяльності й особливо на етапі підготовки до змагань змінюється відповідно до індивідуальних циклічних показників енергетичного метаболізму $[1,11]$. Тому зміна станів спортсменів вивчалася шляхом здійснення досліджень двічі на день і через певний проміжок часу. Також принциповим положенням було паралельне визначення дисперсії показників, виходячи $з$ другої авторської концептуалізації відносно критерію стабільності станів спортсмена.

Деякі результати пілотного дослідження представлено на рис. 1-5. 
Уранці

DATE $=09.08 .2013$

Tree Diagram for 7 Cases

Single Linkage

Euclidean distances

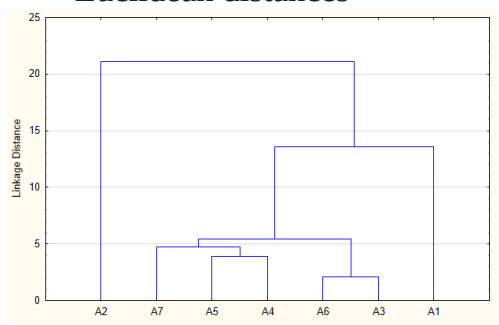

\begin{tabular}{|c|c|c|}
\hline $\begin{array}{c}\text { Case } \\
\text { № }\end{array}$ & $\overline{\bar{X}}$ & $\mathrm{~m}$ \\
\hline A1 & 79,59 & 3,18 \\
\hline A2 & 77,46 & 3,12 \\
\hline A3 & 87,19 & 3,39 \\
\hline A4 & 84,59 & 3,30 \\
\hline A5 & 85,09 & 3,33 \\
\hline A6 & 86,67 & 3,37 \\
\hline A7 & 84,77 & 3,34 \\
\hline \multicolumn{2}{|c|}{ a }
\end{tabular}

Увечері

DATE $=09.08 .2013$

Tree Diagram for 7 Cases

Single Linkage

Euclidean distances

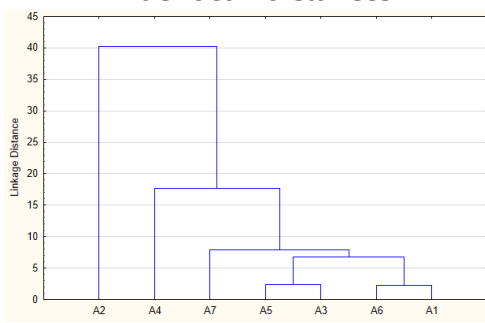

\begin{tabular}{|c|c|c|}
\hline $\begin{array}{c}\text { Case } \\
\text { № }\end{array}$ & $\overline{\bar{X}}$ & $\mathrm{~m}$ \\
\hline A1 & 77,44 & 3,16 \\
\hline A2 & 88,47 & 3,46 \\
\hline A3 & 78,42 & 3,17 \\
\hline A4 & 69,07 & 2,97 \\
\hline A5 & 79,21 & 3,19 \\
\hline A6 & 77,73 & 3,16 \\
\hline A7 & 75,46 & 3,11 \\
\hline
\end{tabular}

Уранці через 3 міс

DATE $=11.11 .2013$

Tree Diagram for 7 Cases

Single Linkage

Euclidean distances

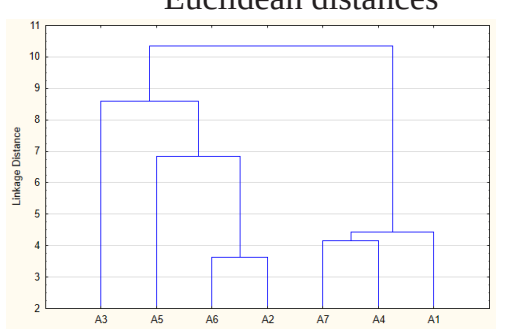

\begin{tabular}{|c|c|c|}
\hline $\begin{array}{c}\text { Case } \\
\text { № }\end{array}$ & $\overline{\bar{X}}$ & $\mathrm{~m}$ \\
\hline A1 & 74,21 & 3,08 \\
\hline A2 & 79,67 & 3,21 \\
\hline A3 & 83,22 & 3,28 \\
\hline A4 & 74,75 & 3,10 \\
\hline A5 & 81,77 & 3,26 \\
\hline A6 & 79,48 & 3,21 \\
\hline A7 & 76,11 & 3,13 \\
\hline
\end{tabular}

Рис. 1. Візуалізація процесів таксономії показників функціонального стану спортсменів-біатлоністів чоловіків методом одиночного зв'язку

Уранці

DATE $=09.08 .2013$

Tree Diagram for 7 Cases

Ward's method

Euclidean distances

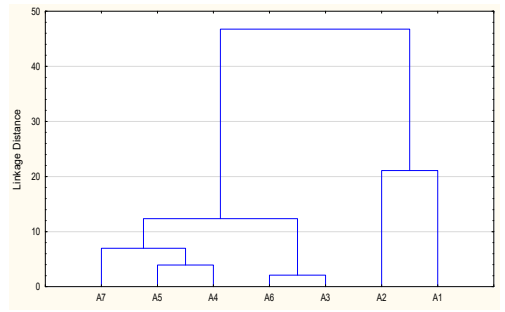

\begin{tabular}{|c|c|c|}
\hline $\begin{array}{c}\text { Case } \\
\text { № }\end{array}$ & $\overline{\bar{X}}$ & $\mathrm{~m}$ \\
\hline A1 & 79,59 & 3,18 \\
\hline A2 & 77,46 & 3,12 \\
\hline A3 & 87,19 & 3,39 \\
\hline A4 & 84,59 & 3,30 \\
\hline A5 & 85,09 & 3,33 \\
\hline A6 & 86,67 & 3,37 \\
\hline A7 & 84,77 & 3,34 \\
\hline
\end{tabular}

Увечері

DATE $=09.08 .2013$

Tree Diagram for 7 Cases Ward's method

Euclidean distances

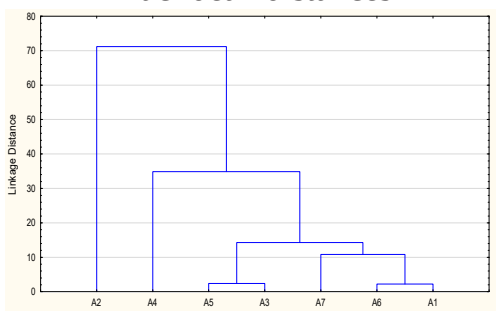

\begin{tabular}{|c|c|c|}
\hline $\begin{array}{c}\text { Case } \\
\text { № }\end{array}$ & $\overline{\bar{X}}$ & $\mathrm{~m}$ \\
\hline A1 & 77,44 & 3,16 \\
\hline A2 & 88,47 & 3,46 \\
\hline A3 & 78,42 & 3,17 \\
\hline A4 & 69,07 & 2,97 \\
\hline A5 & 79,21 & 3,19 \\
\hline A6 & 77,73 & 3,16 \\
\hline A7 & 75,46 & 3,11 \\
\hline \multicolumn{3}{|c|}{6} \\
\hline
\end{tabular}

Уранці через 3 міс

DATE $=11.11 .2013$

Tree Diagram for 7 Cases

Ward's method

Euclidean distances

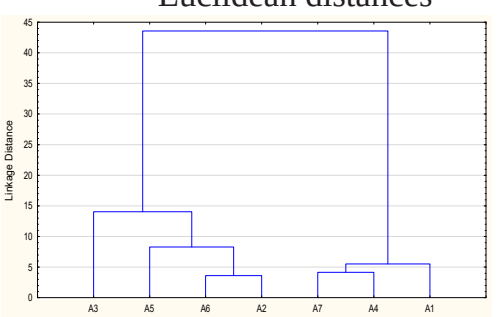

\begin{tabular}{|c|c|c|}
\hline $\begin{array}{c}\text { Case } \\
\text { № }\end{array}$ & $\overline{\bar{X}}$ & $\mathrm{~m}$ \\
\hline A1 & 74,21 & 3,08 \\
\hline A2 & 79,67 & 3,21 \\
\hline A3 & 83,22 & 3,28 \\
\hline A4 & 74,75 & 3,10 \\
\hline A5 & 81,77 & 3,26 \\
\hline A6 & 79,48 & 3,21 \\
\hline A7 & 76,11 & 3,13 \\
\hline \multicolumn{2}{|c|}{ B }
\end{tabular}

Рис. 2. Візуалізація процесів таксономії показників функціонального стану спортсменів-біатлоністів чоловіків методом Уорда 
Перше дослідження

Уранці

DATE $=07.08 .2013$

Tree Diagram for 6 Cases

Ward's method

Euclidean distances

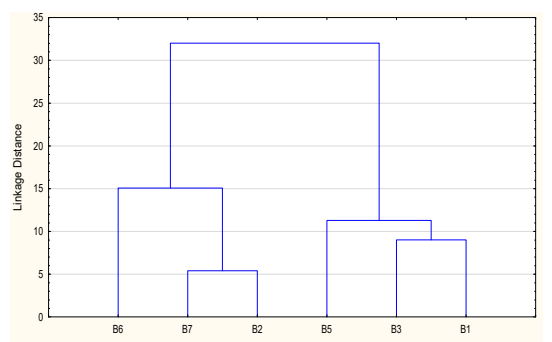

\begin{tabular}{|c|c|c|}
\hline $\begin{array}{c}\text { Case } \\
\text { № }\end{array}$ & $\overline{\bar{X}}$ & $\mathrm{~m}$ \\
\hline B1 & 73,96 & 3,18 \\
\hline B2 & 80,13 & 3,12 \\
\hline B3 & 75,63 & 3,39 \\
\hline B5 & 71,71 & 3,30 \\
\hline B6 & 79,21 & 3,33 \\
\hline B7 & 78,26 & 3,37 \\
\hline
\end{tabular}

a
Друге дослідження

Уранці через 3 дні

DATE $=10.08 .2013$

Tree Diagram for 6 Cases

Ward's method

Euclidean distances

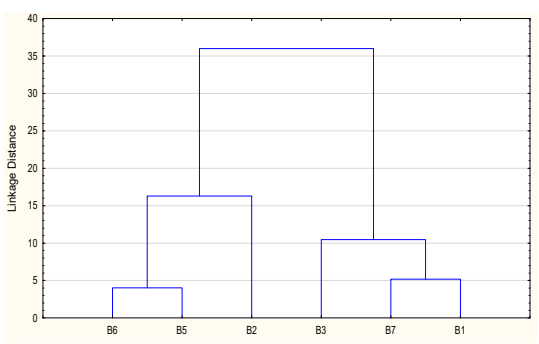

\begin{tabular}{|c|c|c|}
\hline $\begin{array}{c}\text { Case } \\
\text { № }\end{array}$ & $\overline{\bar{X}}$ & $\mathrm{~m}$ \\
\hline B1 & 89,93 & 3,47 \\
\hline B2 & 82,65 & 3,32 \\
\hline B3 & 87,95 & 3,41 \\
\hline B5 & 86,6 & 3,42 \\
\hline B6 & 85,57 & 3,41 \\
\hline B7 & 91,12 & 3,49 \\
\hline
\end{tabular}

б
Друге дослідження

Увечері через 3 дні

DATE $=10.08 .2013$

Tree Diagram for 6 Cases

Ward's method

Euclidean distances

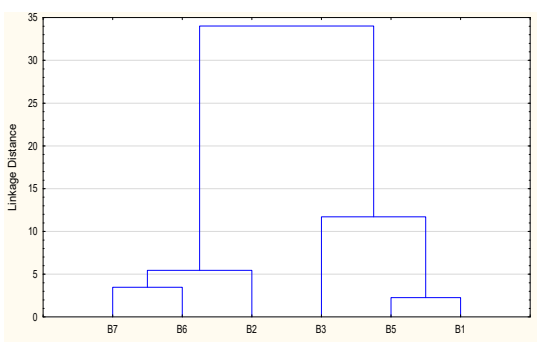

\begin{tabular}{|c|c|c|}
\hline $\begin{array}{c}\text { Case } \\
\text { № }\end{array}$ & $\overline{\bar{X}}$ & $\mathrm{~m}$ \\
\hline B1 & 78,13 & 3,17 \\
\hline B2 & 82,19 & 3,26 \\
\hline B3 & 74,96 & 3,10 \\
\hline B5 & 77,48 & 3,15 \\
\hline B6 & 80,66 & 3,24 \\
\hline B7 & 81,34 & 3,27 \\
\hline
\end{tabular}

B

Рис. 3. Візуалізація процесів таксономії показників функціонального стану спортсменів-біатлоністів жінок методом Уорда

Із наведених на рис. 1-3 даних можна зробити попередні висновки про реальне існування сталих станів у висококваліфікованих спортсменів-біатлоністів, значення показників дисперсії при прогнозуванні зміни станів, а також відносній статевій інваріантності кластерів.

Таксономія показників ергоспірометрії (рис. 4-5) у спортсменів-біатлоністів (жінок) методом одиночного зв'язку та незваженим центроїдним методом виявила цікаві деталі. Перш за все, виявляється наявність пар показників, що в незалежності від методу кластеризації зберігають свою близькість - це пари С4-C1, C7-C5 тощо.

Стосовно збереження кластерів при повторних дослідженнях через місяць - відзначаються суттєві розбіжності як у парних поєднаннях, так і в цілому. Зауважимо, що стійкість сталих станів виявляється досить великою, про що свідчить невеликий розкид даних. Коефіцієнт варіації у більшості випадків не перевищує 5-7 \%. 
Базове дослідження

DATE $=24$

Tree Diagram for 8 Cases

Single Linkage

Euclidean distances

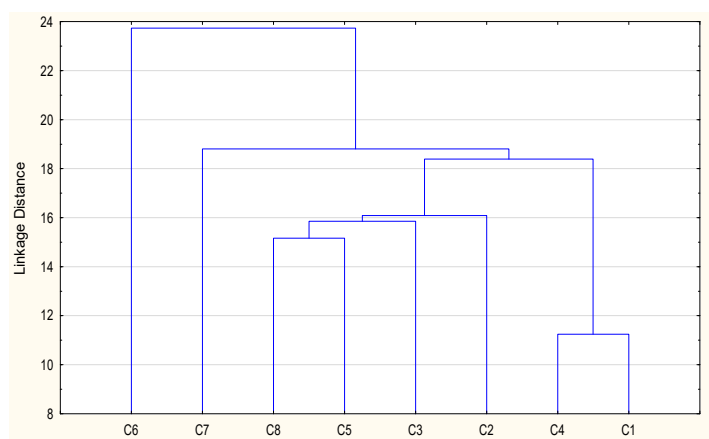

\begin{tabular}{|c|c|c|}
\hline $\begin{array}{c}\text { Case } \\
\text { № }\end{array}$ & $\overline{\bar{X}}$ & $\mathrm{~m}$ \\
\hline C1 & 56,57 & 2,79 \\
\hline C2 & 57,49 & 2,85 \\
\hline C3 & 58,04 & 2,84 \\
\hline C4 & 56,09 & 2,80 \\
\hline C5 & 56,68 & 2,86 \\
\hline C6 & 58,35 & 2,87 \\
\hline C7 & 54,85 & 2,80 \\
\hline C8 & 57,02 & 2,89 \\
\hline
\end{tabular}

a
Дослідження через місяць

DATE $=29$

Tree Diagram for 8 Cases

Single Linkage

Euclidean distances

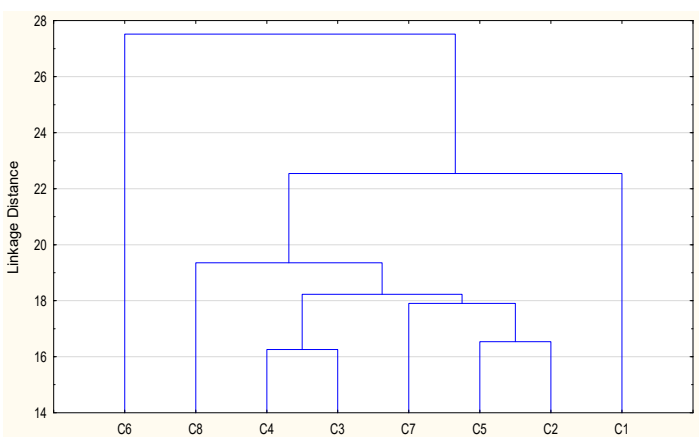

\begin{tabular}{|c|c|c|}
\hline $\begin{array}{c}\text { Case } \\
\text { № }\end{array}$ & $\overline{\bar{X}}$ & $\mathrm{~m}$ \\
\hline $\mathrm{C} 1$ & 55,79 & 2,77 \\
\hline C2 & 57,77 & 2,85 \\
\hline C3 & 58,71 & 2,83 \\
\hline C4 & 56,96 & 2,83 \\
\hline C5 & 59,54 & 2,89 \\
\hline C6 & 57,05 & 2,83 \\
\hline C7 & 56,3 & 2,83 \\
\hline C8 & 57,74 & 2,89 \\
\hline
\end{tabular}

б

Рис. 4. Візуалізація процесів таксономії показників ергоспірометрії стану спортсменів-біатлоністів жінок методом одиночного зв’язку 
Базове дослідження

DATE $=24$

Tree Diagram for 8 Cases

Unweighted pair-group centroid Euclidean distances

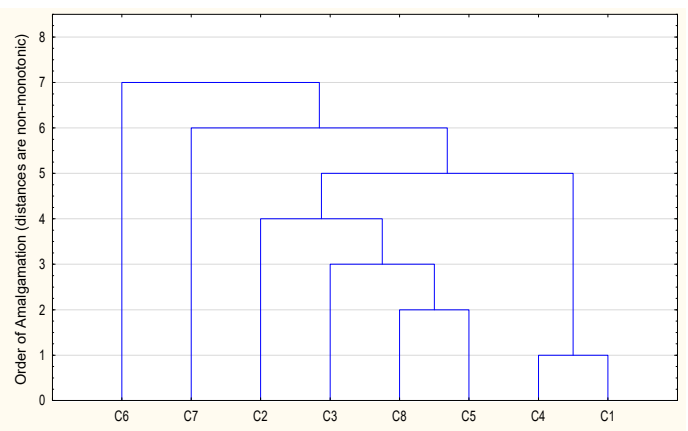

\begin{tabular}{|c|c|c|}
\hline $\begin{array}{c}\text { Case } \\
\text { № }\end{array}$ & $\overline{\bar{X}}$ & $\mathrm{~m}$ \\
\hline $\mathrm{C} 1$ & 56,57 & 2,79 \\
\hline C2 & 57,49 & 2,85 \\
\hline C3 & 58,04 & 2,84 \\
\hline C4 & 56,09 & 2,80 \\
\hline C5 & 56,68 & 2,86 \\
\hline C6 & 58,35 & 2,87 \\
\hline C7 & 54,85 & 2,80 \\
\hline C8 & 57,02 & 2,89 \\
\hline
\end{tabular}

Дослідження через місяць

DATE $=29$

Tree Diagram for 8 Cases

Unweighted pair-group centroid Euclidean distances

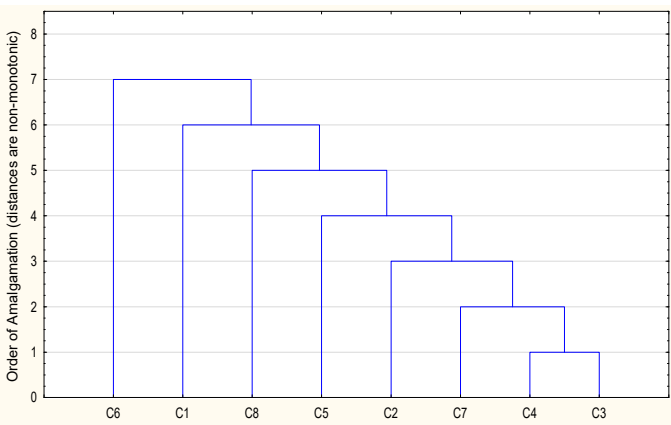

\begin{tabular}{|c|c|c|}
\hline $\begin{array}{c}\text { Case } \\
\text { № }\end{array}$ & $\overline{\bar{X}}$ & $\mathrm{~m}$ \\
\hline $\mathrm{C} 1$ & 55,79 & 2,77 \\
\hline C2 & 57,77 & 2,85 \\
\hline C3 & 58,71 & 2,83 \\
\hline C4 & 56,96 & 2,83 \\
\hline C5 & 59,54 & 2,89 \\
\hline C6 & 57,05 & 2,83 \\
\hline C7 & 56,3 & 2,83 \\
\hline C8 & 57,74 & 2,89 \\
\hline
\end{tabular}

Матриця відстаней

\begin{tabular}{|c|c|c|c|c|c|c|c|c|}
\hline $\begin{array}{c}\text { Case } \\
\text { № }\end{array}$ & C1 & C2 & C3 & C4 & C5 & C6 & C7 & C8 \\
\hline C1 & 0,0 & 28,0 & 18,4 & 11,2 & 21,6 & 25,3 & 20,2 & 32,4 \\
\hline C2 & 28,0 & 0,0 & 21,2 & 31,1 & 16,1 & 35,7 & 27,3 & 22,8 \\
\hline C3 & 18,4 & 21,2 & 0,0 & 19,1 & 15,9 & 24,8 & 25,2 & 22,6 \\
\hline C4 & 11,2 & 31,1 & 19,1 & 0,0 & 23,8 & 26,8 & 24,5 & 32,7 \\
\hline C5 & 21,6 & 16,1 & 15,9 & 23,8 & 0,0 & 23,7 & 18,8 & 15,2 \\
\hline
\end{tabular}

\begin{tabular}{|c|c|c|c|c|c|c|c|c|}
\hline $\begin{array}{c}\text { Case } \\
\text { № }\end{array}$ & C1 & C2 & C3 & C4 & C5 & C6 & C7 & C8 \\
\hline C1 & 0,0 & 31,1 & 23,6 & 24,1 & 38,9 & 30,8 & 22,5 & 38,9 \\
\hline C2 & 31,1 & 0,0 & 18,2 & 26,1 & 16,5 & 41,2 & 17,9 & 19,7 \\
\hline C3 & 23,6 & 18,2 & 0,0 & 16,3 & 18,4 & 34,1 & 18,5 & 26,5 \\
\hline C4 & 24,1 & 26,1 & 16,3 & 0,0 & 25,4 & 27,9 & 18,5 & 29,1 \\
\hline C5 & 38,9 & 16,5 & 18,4 & 25,4 & 0,0 & 41,0 & 24,0 & 19,4 \\
\hline
\end{tabular}




\begin{tabular}{|l|l|l|l|l|l|l|l|l|}
\hline C6 & 25,3 & 35,7 & 24,8 & 26,8 & 23,7 & 0,0 & 29,5 & 26,2 \\
\hline C7 & 20,2 & 27,3 & 25,2 & 24,5 & 18,8 & 29,5 & 0,0 & 28,9 \\
\hline C8 & 32,4 & 22,8 & 22,6 & 32,7 & 15,2 & 26,2 & 28,9 & 0,0 \\
\hline
\end{tabular}

a

\begin{tabular}{|l|l|l|l|l|l|l|l|l|}
\hline C6 & 30,8 & 41,2 & 34,1 & 27,9 & 41,0 & 0,0 & 27,5 & 36,5 \\
\hline C7 & 22,5 & 17,9 & 18,5 & 18,5 & 24,0 & 27,5 & 0,0 & 20,1 \\
\hline C8 & 38,9 & 19,7 & 26,5 & 29,1 & 19,4 & 36,5 & 20,1 & 0,0 \\
\hline
\end{tabular}

б

Рис. 5. Візуалізація процесів таксономії показників ергоспірометрії стану спортсменів-біатлоністів жінок незваженим центроїдним методом

Висновки. Проведена кластеризація функціонального стану в спортсменів у процесі змагальної діяльності підтвердила гіпотезу про наявність у них декількох сталих станів, виявлення та інтерпретація змін яких для досягнення максимального результату на змаганнях можлива при забезпеченні певної тривалості моніторингу та персоналізованого оцінювання траєкторії змін.

1. Більшість методів автоматичної кластеризації станів у спортсменів дають близькі результати.

2. Виділено три типи бар'єрів, що перешкоджають досягненню сталого фізіологічного стану спортсменів або своєчасному його корегуванню. Найбільш впливовий бар'єр пов'язаний із інтерпретацією даних моніторингу показників функціонального стану; другий бар'єр - це обмежений доступ до діагностичних інструментів для оціню-

\section{Література.}

1. Карленко В. П. Оптимизация тренировки квалифицированных биатлонистов на этапе непосредственной подготовки к соревнованиям. Методические рекомендации для тренеров по биатлону / Карленко В. П. - К., 1986. - 24 с.

2. Медико-біологічне забезпечення підготовки спортсменів збірних команд України з олімпійських видів спорту. Навчально-методичний посібник. К.: Олімпійська література, 2009. - 141 с.

3. Платонов В. М. Направления совершенствования системы подготовки спортсменов. Система подготовки спортсменов в олимпийском спорте. Общая теория и ее практические приложения: учебник [для тренеров]: в 2 кн. / В. Н. Платонов. - К.: Олімпійська література, 2015. - Кн. 1. - С. 57-61.

4. Физиология человека. Общая. Спортивная. Возрастная / Солодков А. С., Сологуб Е. - М.: Спортчеловек, 2015. - 620 с.

5. Maximal lactate steady state versus the 20-minute functional threshold power test in well-trained individuals: "Watts" the big deal? / Inglis E. C., Iannetta D., Pass L., Murias J. M. // Int J Sports Physiol Perform. - 2019. - P. 1-7. вання стану спортсменів; третій — пов'язаний iз відсутністю комплексності в системі організації тренувального процесу, зокрема обмежене фінансування діагностичних послуг, брак спеціалістів, недостатня кількість лабораторних досліджень, відсутність інституційної підтримки тощо.

3. Враховуючи, що біологічні об'єкти здатні створювати свої власні норми та постійно гармонізувати свої можливості для забезпечення стабільності функціонування, вкрай потрібна формалізація біологічних концепцій про існування сталих станів.

4. Застосування парадигми сталих станів як комбінації незмінних фізіологічних показників (при не екстремальних впливах зовнішніх факторів) дозволяє суттєво полегшити вирішення завдання прогнозування результатів тренувального процесу в спортсменів.

6. Manipulating graded exercise test variables affects the validity of the lactate threshold and VO2peak / Jamnick N. A., Botella J., Pyne D. B., Bishop D. J. // PLoS One. - 2018. - № 13. - P. 1-21.

7. An examination and critique of current methods to determine exercise intensity / Jamnick N. A., Pettitt R. W., Granata C., Pyne D. B., Bishop D. J. // Sports Med. - 2020.

8. Direct Experimental Evidence for Alternative Stable States: A Review / Schröder A., Persson L., De Roos A., Lundbery P. // Oikos. - 2005. - № 110 (1). - P. 3-19.

9. When can positive interactions cause alternative stable states in ecosystems? / Kéfi S., Holmgren M., Scheffer M. - 2015. - Режим доступу: https://doi.org/10.1111/1365-2435.12601.

10. Multiple "stable" states and the conservation of marine ecosystems / Knowlton N. // Progress in Oceanography. - 2004. - № 60. - Р. 387-396.

11. Ильин Е. П. Психофизиология состояний человека / Ильин Е. П. - СПб.: Питер, 2005. - 412 с: ил. 


\section{References.}

1. Karlenko, V. P., (1986). Optymyzatsyia trenyrovky kvalyfytsyrovannыkh byatlonystov na эtape neposredstvennoi podhotovky k sorevnovanyiam. [Optimization of the training of qualified biathletes at the stage of direct preparation for the competition.]. Metodycheskye rekomendatsyy dlia trenerov po byatlonu. Kyiv, 24. [In Russian].

2. Medyko-biolohichne zabezpechennia pidhotovky sportsmeniv zbirnykh komand Ukrainy z olimpiiskykh vydiv sportu. [Medical and biological care for the training of athletes in Ukrainian national teams in Olympic sports]. Navchalno-metodychnyi posibnyk. (2009). Kyiv: Olimpiiska literatura. 141. [In Ukrainian].

3. Platonov, V. M., (2015). Napravlenyia sovershenstvovanyia systemы podhotovky sportsmenov. Systema podhotovky sportsmenov v olympyiskom sporte. Obshchaia teoryia y ee praktycheskye prylozhenyia: uchebnyk [dlia trenerov]: v $2 \mathrm{kn}$. [Directions of the sportsmen training system improvement. The system of training athletes in Olympic sports. General theory and its practical applications: textbook [for trainers]: in 2 kn.]. K.: Olymp. Lyt., Kn. 1, 57-61. [In Russian].

4. Solodkov, A. S., Solohub, E., (2015). Fyzyolohyia cheloveka. Obshchaia. Sportyvnaia. Vozrastnaia. [Human physiology. General. Sports. Age]. Yzd-vo Sport-chelovek, 620. [In Russian].

5. Inglis, E. C., Iannetta, D., Pass, L., Murias, J. М.б (2019). Maximal lactate steady state versus the 20-minute functional threshold power test in welltrained individuals: "Watts" the big deal? Int J Sports Physiol Perform, 1-7.
6. Jamnick, N. A., Botella, J., Pyne, D. B., Bishop, D. J. (2018). Manipulating graded exercise test variables affects the validity of the lactate threshold and VO2peak. PLoS One, 13, 1-21.

7. Jamnick, N. A., Pettitt, R. W., Granata C., Pyne D. B., Bishop D. J., (2020). An examination and critique of current methods to determine exercise intensity. Sports Med.

8. Schröder, A., Persson, L., De Roos, A., Lundbery, P. (2005). Direct Experimental Evidence for Alternative Stable States: A Review. Oikos, 110 (1), 3-19. URL: http://www.jstor.org/stable/3548414.

9. Kéfi, S., Holmgren, M., Scheffer, M., (2015). When can positive interactions cause alternative stable states in ecosystems? First published: 12 November 2015. URL: https://doi.org/10.1111/1365-2435.12601.

10. Knowlton, N., (2004). Multiple "stable” states and the conservation of marine ecosystems. Progress in Oceanography 60, 387-396.

11. Ylyn, E. P., (2005). Psykhofyzyolohyia sostoianyi cheloveka [Psychophysiology of human states]. SPb.: Pyter, 412. [In Russian]. 